\title{
FALSE ANEURYSM OF THE PROFUNDA FEMORIS ARTERY FOLLOWING NAIL AND PLATE FIXATION OF AN INTERTROCHANTERIC FRACTURE
}

\author{
Report of a Case
}

\author{
A. Fordyce, Oswestry, England \\ From the Rohert Jones and Agnes Hunt Orthopaedic Hospital, Oswestry
}

In its initial phase false aneurysm is an encapsulated haematoma fed by a defect in the wall of an artery and confined by the tissues among which it lies (Dameron 1964). In its fully developed state it may have a cavity with an endothelial lining in continuity through the defect in the arterial wall with that of the artery; it eventually develops a laminated wall of fibrin, organised blood clot and connective tissue. It is the result of incomplete division of an artery, its size limited by the elasticity of the tissues which confine the escaping blood. In the presence of concomitant venous injury, arterio-venous fistula may result. The usual presentation is as a pulsating mass: a bruit may be audible but there is no deleterious effect on the haemodynamics of the cardio-vascular system.

\section{CASE REPORT}

A man aged fifty-six was involved in a road accident in April 1966. He suffered multiple injuries, among which was a comminuted intertrochanteric fracture of the left femur. After resuscitation the fracture was fixed, with some difficulty, by a nail and four-hole plate through a standard lateral approach. Screw holes were drilled in the femur with a compressed air drill.

Nine days after the operation he was noted to have a swollen thigh and to be slightly icteric. Serum bilirubin was $0.7 \mathrm{mg}$. per cent and there was a weak positive direct van den Bergh's reaction. Twenty-five days after operation he was noted still to have a tense swelling in the anterior aspect of the left thigh which was only slightly tender. It was not felt to pulsate and the overlying skin was not unduly warm or inflamed. At this time the patient was transferred to The Robert Jones and Agnes Hunt Orthopaedic Hospital, Oswestry.

On admission the presence of a tense, nonpulsatile swelling was confirmed; the original wound was well healed and showed no sign of infection. There was no sign of cardiac decompensation, peripheral pulses in the limb were palpable and capillary return was normal. There was no pyrexia. Haemoglobin was 10.4 g. per $100 \mathrm{ml}$. White blood count was 6,200 per cu. $\mathrm{mm}$. and erythrocyte sedimentation rate was $54 \mathrm{~mm}$. in the first hour. A faint bruit was audible over the swelling, which was noted to increase marginally in size over the next twelve hours.

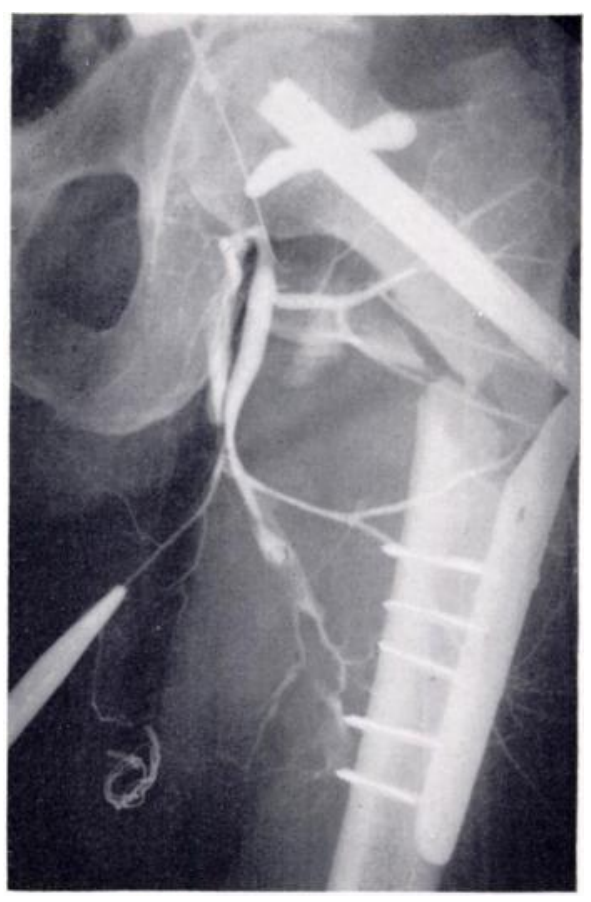

FIG. 1

Arteriograph obtained at operation showing the profunda artery. 
Operation-The patient was taken to the operating room and anaesthetised. Percutaneous arteriography showed the femoral artery to be intact. An anterior longitudinal incision was made to expose the femoral artery and the origin of the profunda artery. Open arteriography showed that the profunda artery was distorted and that leakage was occurring opposite the lower two screws, which penetrated the medial cortex of the femoral shaft (Fig. 1). Exploration was continued between the vastus medialis and the adductors. A haematoma, partly organised, was found and evacuated, two pints of blood clot being removed. The profunda artery and companion veins were exposed and opposite the fourth screw the artery showed a wound through both medial and lateral walls which bled vigorously. Its companion veins showed multiple lacerations.

Haemostasis was secured by ligation of the bleeding vessels above and below, and the wound closed. The patient made a good recovery.

\section{DISCUSSION}

This condition, though fairly common after accidental trauma, is a rare complication of surgery. Elkin (1948) in a personal series of over 650 cases was able to attribute only five to surgical trauma. Dameron (1964) reported a case of false aneurysm of the profunda

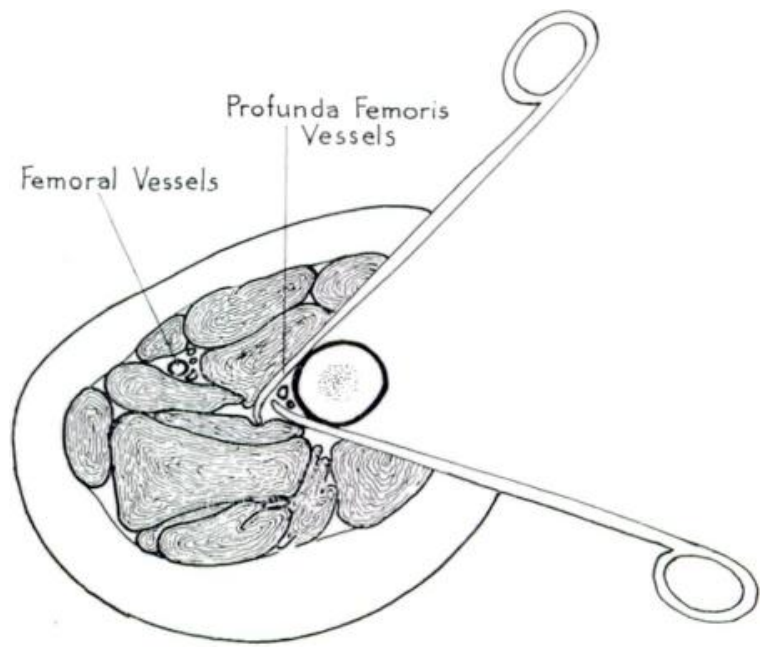

Fig. 2

Cross-section of the thigh from J. C. B. Grant's An Atlas of Anatomy modified to show bone levers in position through a lateral approach.

artery presenting eight months after nail plate fixation of an intertrochanteric fracture; he ascribed it to damage by a screw. Meyer and Slager (1964) reported a case presenting sixteen weeks after nail-plate fixation of an abduction osteotomy, the false aneurysm again presenting in the profunda artery opposite a protruding screw. Bassett and Houck (1964) reported a case presenting ten years after osteotomy, again in the profunda artery at the level of a protruding screw.

In the case described here, the patient presented much earlier than those of other writers, and early exploration provided information which may indicate a different cause of the lesion. Wounds were found on both sides of the artery, suggesting that it had been transfixed, whereas previous cases appear to have developed from laceration of the vessel on one side only. It is suggested that the transfixing agent was the drill used to prepare the screw holes. If so it is remarkable that this lesion does not occur more often, in view of the frequency of this fracture, the frequency of subtrochanteric osteotomy, and the proximity of the profunda 
artery to the medial side of the femoral shaft. It is suggested that a further factor predisposing to this injury is malplacement of bone levers, as illustrated in Figure 2, thus fixing the vessel and allowing its injury by the perforating drill.

The likelihood of injury to the profunda artery will be lessened if: 1) Care is taken to prevent the drill plunging into the soft tissues of the medial side of the thigh after penetrating the medial cortex of the femur; this may be achieved by the use of short drills or drills with a guard; 2) screws of the correct length are selected; 3) bone levers are carefully placed.

I wish to thank Mr M. P. Robinson for his help and advice in the preparation of this paper, and for permitting me to publish the case. My thanks are due also to Mr B. Southern, Medical Photographic Department, and Mr D. Foster, Art Therapy Department of The Robert Jones and Agnes Hunt Orthopaedic Hospital, for the illustrations; and Mrs Glenys Davies for help in the preparation of the paper.

\section{REFERENCES}

Bassett, F. H., III, and Houck, W. S., Jun. (1964): False Aneurysm of the Profunda Femoris Artery after Subtrochanteric Osteotomy and Nail-plate Fixation. Journal of Bone and Joint Surgery, 46-A, 583.

Dameron, T. B., Jun. (1964): False Aneurysm of Femoral Profundus Artery Resulting from Internal-fixation Device (Screw). Journal of Bone and Joint Surgery, 46-A, 577.

Elkin, D. C. (1948): Aneurysm Following Surgical Procedures. Report of Five Cases. Annals of Surgery, $127,769$.

Grant, J. C. B. (1956): An Atlas of Anatomy. Fourth edition. London: Baillière, Tindall \& Cox Ltd.

Meyer, T. L., Jun., and Slager, R. F. (1964): False Aneurysm following Subtrochanteric Osteotomy. Journal of Bone and Joint Surgery, 46-A, 581. 